\title{
Comparison of the Proteins and Polypeptides of the Eight Serotypes of Ureaplasma urealyticum by Isoelectric Focusing and Sodium Dodecyl Sulfate-Polyacrylamide Gel Electrophoresis
}

\author{
IFTIKHAR A. SAYED† AND GEORGE E. KENNY \\ Department of Pathobiology, School of Public Health and Community Medicine, University of Washington, \\ Seattle, Washington 98195
}

\begin{abstract}
Analysis of representative strains of the eight human serotypes of Ureaplasma urealyticum by polyacrylamide gel electrophoresis identified 36 to 40 polypeptides for each strain. At least $80 \%$ of the peptides were common among strains, but unique major peptides were identifiable in ureaplasmic types. Type 1 had a polypeptide of 85,000 daltons, type 3 had a polypeptide of 72,000 daltons, type 5 had a polypeptide of 64,000 daltons, and type 8 had a polypeptide of 95,000 daltons. The unique polypeptides in types 1 and 8 were identified as membrane components. Two common major components of 44,000 and 70,000 daltons were observed. Several components were common to some, but not all, serotypes. Patterns obtained from $U$. urealyticum strains were strikingly different from the patterns of Acholeplasma laidlawii, Mycoplasma gallisepticum, Mycoplasma arginini, and Mycoplasma hominis. Isoelectric focusing demonstrated a unique membrane protein for type 1 at $\mathrm{pK} 6.4$, whereas type 8 possessed an assembly of five unique proteins at pK 7.0. Ureaplasmata were strongly similar to each other by isoelectric focusing, but strikingly different from members of the other genera studied. Although a filtered, strongly buffered dialysate medium with $1 \%$ serum and $30 \mathrm{mM}$ urea was used both to maximize yields and to minimize contamination, minor contaminants were detected, which comigrated with horse transferrin (pK 6.0 ) and cytochrome $c$ (molecular weight, 14,000). The similarities of the polypeptide patterns of $U$. urealyticum strains affirm their close relationships to each other, in contrast to the diversity shown in the genus Mycoplasma, and our recognition of type-specific membrane peptides will enhance the identification of serotypes and the classification of strains.
\end{abstract}

The "T" Mycoplasma strains, isolated from humans, have been classified as a single species, Ureaplasma urealyticum, with eight serotypes (23). The basis for differentiation of the serotypes was the fact that strains of $U$. urealyticum can be typed reasonably specifically by the metabolic inhibition test or by growth inhibition on agar. However, the metabolic inhibition test shows much greater species specificity than type specificity in the differentiation of Mycoplasma species. Thus, we really do not know whether types of $U$. urealyticum are as similar to each other as strains of a classic Mycoplasma species or whether the relationship between types is more like that observed between Mycoplasma species which are serologically related (7).

The identification of Mycoplasma species and the determination of the relationships among

$\dagger$ Present address: Division of Arthritis, Department of Internal Medicine and College of Medicine, University of Utah, Salt Lake City, UT, 84132. strains of a species and of related species have been carried out by polyacrylamide gel electrophoresis; patterns from related organisms are quite similar, and those from unrelated organisms are markedly dissimilar (17). The purpose of the present study was to compare the polypeptides and proteins of representative strains of the eight serotypes of $U$. urealyticum by examining both molecular weights (sodium dodecyl sulfate [SDS]-polyacrylamide gel electrophoresis) and isoelectric points (isoelectric focusing). Comparisons were also made with strains of Mycoplasma and Acholeplasma species, and extensive control measures for monitoring contamination with medium components were carried out to verify the results.

\section{MATERIALS AND METHODS}

Mollicutes. The strains obtained from the American Type Culture Collection, Rockville, Md., for use in this study were Acholeplasma laidlawii ATCC 
14192, Mycoplasma gallisepticum ATCC 15302, Mycoplasma hominis ATCC 14027, U. urealyticum type 1 ATCC 27813, type 2 ATCC 27814, type 3 ATCC 27815 , type 4 ATCC 27816 , type 5 ATCC 27817 , type 6 ATCC 27818, and type 7 ATCC 27819. U. urealyti. cum type 8 as $960(\mathrm{cl} \times 8)$ and Mycoplasma arginini strain G-230 were kindly supplied by M. C. Shepard and M. F. Barile, respectively.

Stock solutions and medium supplements. The following solutions were sterilized by filtration through a membrane filter (pore diameter, $0.22 \mu \mathrm{m}): 1 \mathrm{M} 2-(N$ morpholino)ethanesulfonic acid (MES), pH 6.0; $1 \mathrm{M}$ $\mathrm{N}$-tris (hydroxymethyl)methyl-2-aminoethanesulfonic acid (TES) $\mathrm{pH} 7.3 ; 1 \mathrm{M}$ sodium sulfite; $0.5 \mathrm{M}$ dithioerythritol; and $1 \mathrm{M}$ urea. Agamma horse serum (Flow Laboratories, Rockville, Md.) was refiltered to ensure removal of insoluble serum precipitates. Phenol red (sodium salt; 1\%), phosphate-buffered saline (pH 7.1; lacking $\mathrm{Mg}^{2+}$ and $\mathrm{Ca}^{2+}$ [3]), and TES-saline (5 mM TES plus $150 \mathrm{mM} \mathrm{NaCl}$ [6]) were sterilized by autoclaving.

Culture media. Soy peptone-fresh yeast dialysate medium $(5,8)$ was sterilized by filtration rather than by autoclaving. The routine culture medium used contained dialysate broth supplemented with $5 \%$ agamma horse serum, $30 \mathrm{mM}$ MES buffer, $10 \mathrm{mM}$ urea, $100 \mathrm{U}$ of penicillin per $\mathrm{ml}$, and $0.001 \%$ phenol red (final $\mathrm{pH}$, 6.1). Culture methods were as described previously (8, 20 ). The mass cultivation medium for $U$. urealyticum strains contained dialysate broth supplemented with $1 \%$ (vol/vol) agamma horse serum, $90 \mathrm{mM}$ MES, 30 $\mathrm{mM}$ urea, $1 \mathrm{mM}$ fresh sodium sulfite (reducing agent [21]), and $100 \mathrm{U}$ of penicillin per $\mathrm{ml}$. An actively growing culture (which had just shown color change on the indicator) was diluted 1:1,000 into 10 to 12 liters of growth medium (approximately $2 \times 10^{4}$ colonyforming units per $\mathrm{ml}$ ) and incubated aerobically at $37^{\circ} \mathrm{C}$ for 28 to $36 \mathrm{~h}$ (final yield, $\sim 6 \times 10^{7}$ colonyforming units or $2.25 \mu \mathrm{g}$ of protein per $\mathrm{ml}$ ). Acholeplasma and Mycoplasma strains were grown in dialysate broth containing $10 \%$ agamma horse serum, 100 $\mathrm{U}$ of penicillin per $\mathrm{ml}$, and $20 \mathrm{mM}$ TES at $\mathrm{pH} 7.3$. Cultures in late log phase were centrifuged at 12,000 $\times g$ for $40 \mathrm{~min}$. The sediment was washed three times with a total of 2 liters of TES-saline. Cells were suspended in $5 \mathrm{ml}$ of sterile distilled water, freeze-dried, and stored at $-70^{\circ} \mathrm{C}$. For analysis, cells were reconstituted with sterile water $(10 \mathrm{mg}$ of protein per $\mathrm{ml})$ and sonicated at $4^{\circ} \mathrm{C}$ for a total of 2 min per ml of suspension. Bovine serum albumin was used as the standard for protein determination (10).

Optimal conditions for lysis of organisms for membrane preparation. Two methods of lysis were tested, alkaline (carbonate lysis [4]) and saponin (digitonin lysis [18]). Three-times-washed live organisms were suspended in $0.15 \mathrm{M} \mathrm{NaCl}$ at $37^{\circ} \mathrm{C}$, and $0.1 \mathrm{ml}$ of the suspension was mixed with $2.5 \mathrm{ml}$ of an appropriate buffer or digitonin at a concentration sufficient to give an optical density of 0.3 to 0.35 at $500 \mathrm{~nm}$. For alkaline lysis, the following buffer solutions were prepared at $50 \mathrm{mM}$ concentrations in $50 \mathrm{mM} \mathrm{NaCl}$ : citric acidsodium citrate, $\mathrm{pH} 3.0,4.0$, and 5.0; MES, pH 6.0; TES, $\mathrm{pH} 7.0$ and 8.0; and carbonate-bicarbonate at a range of $\mathrm{pH} 9$ to 11 . Digitonin (98\% pure; BDH Chemicals, Ltd.; obtained from Gallard Schlessinger Corp., Carle
Place, N.Y.) was dissolved in $0.25 \mathrm{M} \mathrm{NaCl}$, and serial twofold dilutions were prepared in $0.25 \mathrm{M} \mathrm{NaCl}$ from an $80 \mu \mathrm{M}$ stock solution. The lytic abilities of the various buffers and digitonin were tested by adding 0.1 $\mathrm{ml}$ of cell suspension at $37^{\circ} \mathrm{C}$ to $2.5 \mathrm{ml}$ of agent also at $37^{\circ} \mathrm{C}$. The optical density of the cell suspension was measured at intervals at $500 \mathrm{nM}$. Percent lysis was calculated by dividing the observed density by the control value.

Preparation of membrane and cytoplasmic fractions. Cells were lysed by using either carbonatebicarbonate buffer or digitonin. Washed cells $(5 \mathrm{ml}$ containing a total of $30 \mathrm{mg}$ of cell protein) were suspended in a $200-\mathrm{ml}$ volume of $50 \mathrm{mM}$ carbonate-bicarbonate buffer in $50 \mathrm{mM} \mathrm{NaCl}$ at $\mathrm{pH} 10.2$ and $37^{\circ} \mathrm{C}$ and incubated for $10 \mathrm{~min}$; the $\mathrm{pH}$ was adjusted to 7.0 by adding $10 \mathrm{ml}$ of $1 \mathrm{M}$ MES buffer, pH 5.5. The viscosity of the suspension was reduced by the addition of $2 \mathrm{mg}$ of deoxyribonuclease I (bovine pancreas) and incubation at $37^{\circ} \mathrm{C}$ for $15 \mathrm{~min}$. Membranes were separated from the cytoplasmic fraction by centrifugation. Sediment 1 was obtained by centrifuging the lysed cell suspension at $4,000 \times g$ for $10 \mathrm{~min}$. Sediment 2 was the pellet obtained by centrifuging the supernatant at $40,000 \times g$ for $1.5 \mathrm{~h}$, and the supernatant was the cytoplasmic fraction. Sediments 1 and 2 were each washed three times with TES-saline. The cytoplasmic fraction was centrifuged again at $40,000 \times g$ for $2 h$ to remove sedimentable membrane components. The supernatant was dialyzed exhaustively against TES-saline for $48 \mathrm{~h}$, concentrated 40 - to 50 -fold by placing the casings in Aquacide II-A (a hydrophilic polyethylene glycol; molecular weight, 250,000; Calbiochem, La Jolla, Calif.), and stored frozen at $-70^{\circ} \mathrm{C}$. Digitonin lysis was carried out in the same manner by using 200 $\mathrm{ml}$ of $40 \mu \mathrm{M}$ digitonin in $0.25 \mathrm{M} \mathrm{NaCl}$ with incubation for $15 \mathrm{~min}$ at $37^{\circ} \mathrm{C}$. Adjustment of the $\mathrm{pH}$ was not required before the addition of $2 \mathrm{mg}$ of deoxyribonuclease I. The remaining procedure was identical to that used for alkaline lysis of cells.

Polyacrylamide gel electrophoresis. Electrophoresis was carried out in a model SE-500 (Hoeffer Scientific Instruments, San Francisco, Calif.) electrophoresis apparatus with $1.5-\mathrm{mm}$-thick polyacrylamide gels. The procedure was adapted from that of Laemmli (9); however, there was $3.5 \%$ cross-linkage in the gel and dithioerythritol was used instead of mercaptoethanol. The test sample contained $140 \mu \mathrm{g}$ of total cell protein. Gels were stained with $0.2 \%$ Coomassie brilliant blue R-250 in methanol-water-acetic acid (4:5:4.5: 1) at $56^{\circ} \mathrm{C}$ for $1 \mathrm{~h}$. Slabs were destained with waterethyl alcohol-acetic acid $(8: 3: 1)$ at room temperature. Destained gels were stored in aqueous $6 \%$ (vol/vol) acetic acid-2\% (vol/vol) glycerol.

Isoelectric focusing. Isoelectric focusing in polyacrylamide gels in the $\mathrm{pH}$ range 3 to 10 was carried out in Multiphor 2117 apparatus (LKB Instruments, Inc., Rockville, Md.), as described elsewhere $(19,22)$. The samples were dissolved in equal volume of a sample-solubilizing solution $(6 \mathrm{mM}$ dithioerythritol, $500 \mathrm{mM}$ glycerol, and $20 \mathrm{mM}$ Tween-20 in water). The sample $(80 \mu \mathrm{g}$ of protein) was applied directly onto the surface of the gel. Polyacrylamide gels were prepared in a manner similar to that described previously (19); however, urea was replaced with $500 \mathrm{mM}$ glycerol, and 
Triton X-100 was replaced with Tween-20. The "anolyte" was $0.5 \mathrm{M}$ phosphoric acid, and the "catholyte" was $70 \mathrm{mM}$ ethylenediamine. Samples were focused at a constant current of $35 \mathrm{~mA}$ for 2.25 to $2.5 \mathrm{~h}$ or until voltage had increased to $1,000 \mathrm{~V}$. The $\mathrm{pH}$ gradient, formed in the flat bed, was measured (at points $0.5 \mathrm{~cm}$ apart) on the surface of the gel by using an MI-410 micro-glass electrode and a $1.2 \mathrm{~mm} \mathrm{pH}$ probe (Microelectrodes, Inc. Londonderry, N.H).

Serum protein fractions. The following commercially available equine serum fractions (U.S. Biochemicals, Cleveland, Ohio) were used as controls for comparative analysis: albumin, gamma globulins, and transferrin. Bovine serum proteins included albumin, alpha globulins, beta globulins, gamma globulins, transferrin, glycoprotein, Cohn fraction VI, and lipoprotein Cohn fraction $111-0 ; 10$ to $12 \mu \mathrm{g}$ of each protein was used per sample. Agamma horse serum and whole horse serum were titrated with $1 \mathrm{~N} \mathrm{HCl}$ to a pH of 6.0. The precipitate was collected by centrifugation and washed three times with a $150 \mathrm{mM} \mathrm{NaCl}$ solution $(\mathrm{pH}$ 6.0 ).

\section{RESULTS}

Comparison of polypeptides by molecular weight. From 36 to 40 polypeptides (protein bands) could be distinguished in samples which contained $140 \mu \mathrm{g}$ of protein (Fig. 1). Peptides of similar molecular weight were observed for the $U$. urealyticum serotypes at both the high-molecular-weight end of the gel (greater than 90,000 daltons) and at the low end of the gel (less than 30,000 daltons), whereas in the middle range of the gel striking differences were observed among serotypes (Fig. 1). Serotypes 1 and 8 possessed distinct major peptides of 85,000 and 95,000 daltons, respectively, which were not found in the other types. Types 3 and 5 contained polypeptides of 72,000 and 64,000 daltons, respectively, which also were not found in other types. Some polypeptides were located in only certain types; e.g., polypeptide 59,000 was found in types 6,7 , and 8 . A polypeptide of 51,000 daltons was common in types $2,4,5$, and 8 , whereas a 46,000 dalton polypeptide was observed in types $2,4,5$, 7 , and 8 . However, certain prominent polypeptides (e.g., polypeptides of 44,000 and 70,000 daltons) were common to all types (Fig. 1, upper two arrowheads). The polypeptide profiles of the $U$. urealyticum strains were strikingly different from those of strains of Mycoplasma and Acholeplasma (Fig. 2). M. hominis ATCC 14027 and $M$. arginini G-230, known to be serologically related $(7,21)$, showed only slight similarities in patterns, and the level of similarity was far less than the similarities seen among the $U$. urealy. ticum strains. As expected from their unique serological and biochemical features (7), A. laidlawii ATCC 14192 and M. gallisepticum ATCC 15302 were not only strikingly different from

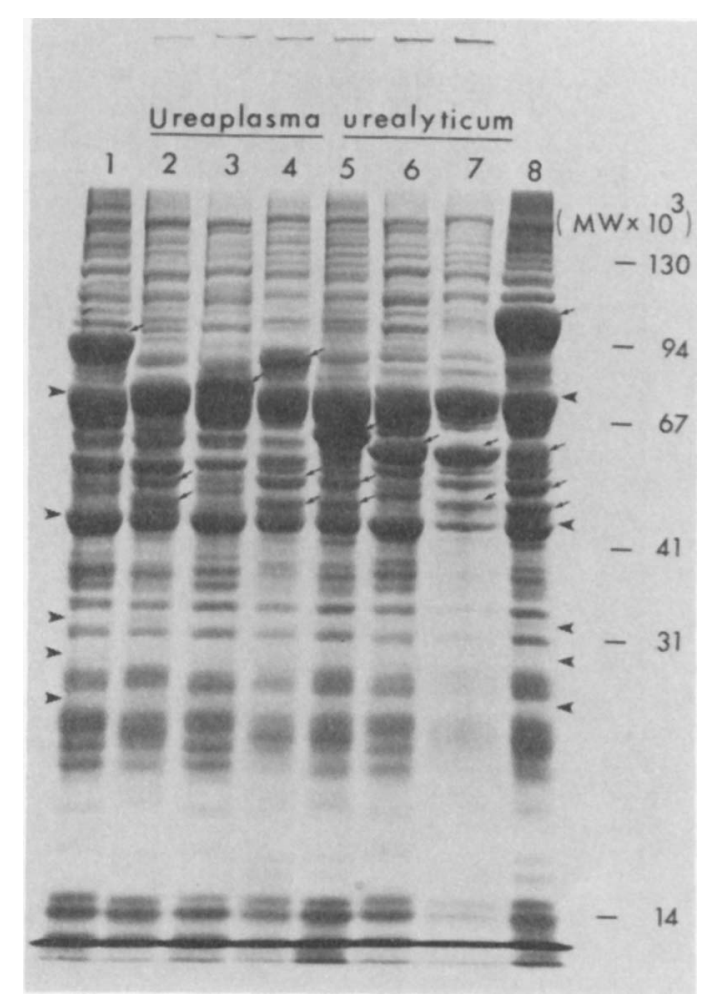

Frg. 1. Analysis of ureaplasmic whole-cell lysates by SDS.polyacrylamide gel electrophoresis. Numbers across the top indicate serotypes 1 to 8 of $U$. urealy. ticum strains. The molecular weights (MW) of poly. peptides were estimated by utilizing a scale derived from the values of standard proteins with known molecular weights plotted against their relative mobilities (in millimeters); the standards employed were $\beta$-galactosidase (130,000 daltons), phosphorylase B (94,000 daltons), bovine serum albumin (68,000 daltons), alcohol dehydrogenase (41,000 daltons), beef pancreas deoxyribonuclease I (31,000 daltons), human gamma globulins (reduced) $(50,000$ and 25,000 daltons), lysozyme (14,300 daltons), and ribonuclease (13,600 daltons). Slanted arrows indicate peptides unique to a type.

each other but also markedly different from the other organisms.

Comparison of organisms by pK value. The patterns from $U$. urealyticum strains showed strong similarities to each other but little resemblance to strains of Mycoplasma and Acholeplasma when compared by isoelectric focusing (Fig. 3). Serotype 1 contained unique proteins with $\mathrm{pK}$ values of 6.4 , and the strains of types $2,4,5$, and 7 contained proteins which focused at $\mathrm{pH} 5.3$ and which were not found in the other strains tested. A. laidlawii ATCC 14192 showed a number of proteins in the acidic range ( $\mathrm{pH} 3.7$ to 4.8 ) not seen in any of the other 


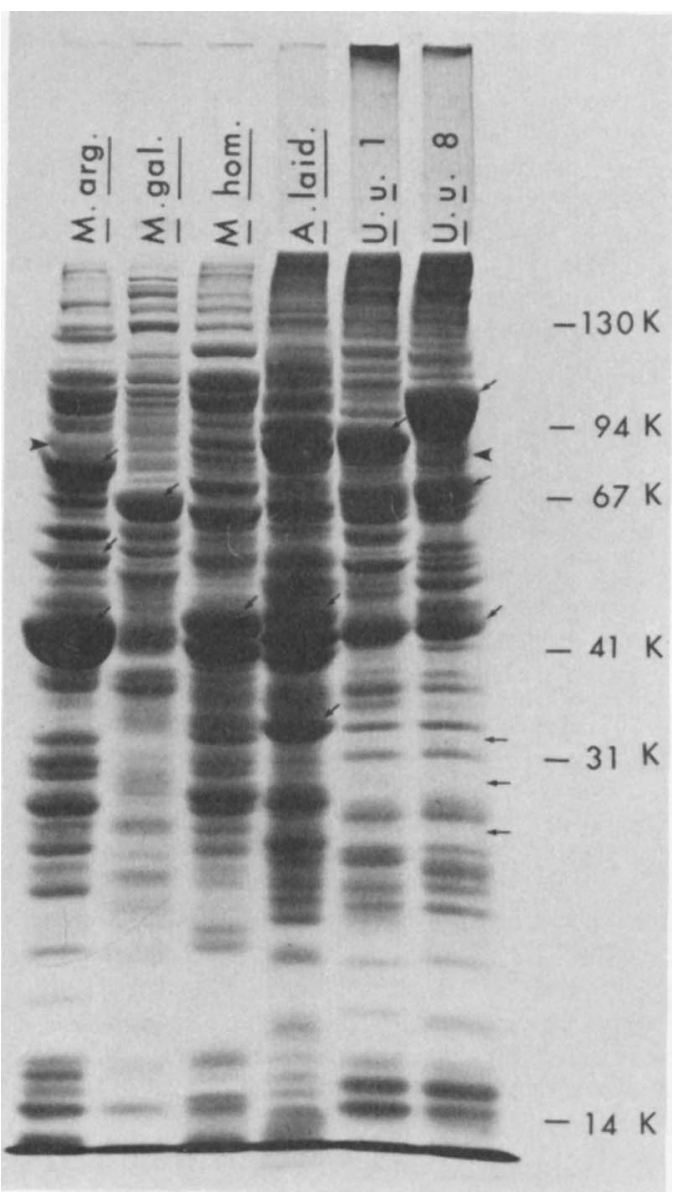

FIG. 2. Polyacrylamide gel electrophoresis profiles of strains of $U$. urealyticum serotypes 1 and 8 , three strains of Mycoplasma species, and one strain of $A$. laidlawii. From left to right the gels contained $M$. arginini G-230, M. gallisepticum ATCC 15302, M. hominis ATCC 14027, A. laidlawii ATCC 14192, a strain of $U$. urealyticum type 1 , and a strain of $U$. urealyticum type 8 . The molecular weights were estimated by using standard proteins of known molecu. lar weights (see legend to Fig. 1). Slanted arrows indicate unique components. Horizontal arrows indicate taxonomically important gaps.

strains examined. Although $M$. arginini G-230 had shown some similarities to $M$. hominis ATCC 14027 by polyacrylamide gel electrophoresis (Fig. 2), less similarity was observed by isoelectric focusing; $M$. arginini G-230 showed a number of acidic proteins ( $\mathrm{pH} 5.0$ to 5.5) not seen in $M$. hominis ATCC 14027.

Comparison of membrane and cytoplasmic fractions. Lytic conditions for the $U$. urealyticum strains were studied to determine the optimum method for separation of membranes and cytoplasm. The lysis of $U$. urealyti. cum was a function of pH (Fig. 4); there was $50 \%$ lysis at $\mathrm{pH} \mathrm{9.8,70 \%} \mathrm{lysis} \mathrm{at} \mathrm{pH} \mathrm{9.8,70 \%} \mathrm{lysis} \mathrm{at}$ $\mathrm{pH} 10.0$, and greater than $80 \%$ lysis at $\mathrm{pH} 10.4$. For further study, $\mathrm{pH} 10.2$ was used to prepare membranes and cytoplasm to minimize destruction of membrane proteins while still providing effective lysis of cells. $M$. gallisepticum ATCC 15302 was the most sensitive organism in the experiment, showing $85 \%$ lysis at $\mathrm{pH} 9.4$ and significant dissolution ( $96 \%$ cell lysis) at $\mathrm{pH} 10.0$. In contrast, A. laidlawii ATCC 14192 was the most resistant organism, showing only $50 \%$ lysis at $\mathrm{pH} 10$. The $U$. urealyticum strains and $M$. hominis ATCC 14027 were markedly sensitive to digitonin lysis, whereas $M$. gallisepticum and A. laidlawii were less sensitive (Fig. 5). For further experiments, $40 \mu \mathrm{M}$ digitonin was used because with it $70 \%$ lysis could be achieved for the four organisms.

Membrane profiles obtained by SDS-polyacrylamide gel electrophoresis did not differ greatly from the whole-cell profiles of strains of serotypes 1 and 8 ; however, the cytoplasmic fractions were strikingly different from both the membrane fractions and the whole-cell fractions (Fig. 6). A 95,000-dalton polypeptide, which was clearly unique to type 8 (Fig. 1), was found to be a membrane component (Fig. 6). An 85,000-dalton polypeptide, which was unique to type 1 , was also a membrane component. Nearly all of the peptides with molecular weights greater than 70,000 were found in the membrane fraction. A component of 70,000 daltons, which was observed in all of the ureaplasmic serotypes, was found to be clearly cytoplasmic (Fig. 6, tracks 3 , 7,10 , and 14). Both methods of lysis appeared to give effective separation of cytoplasm from membrane, but certain differences were evident. The common component of 70,000 daltons was recovered more poorly by digitonin lysis than by alkaline lysis of type 8 cells (Fig. 6), whereas no such differentiation was observed in lysis of type 1 cells. On the other hand, the membrane component of 95,000 daltons contaminated the cytoplasm of type 8 cells when the cytoplasmic fraction was prepared by alkaline lysis (Fig. 6). We found that the cytoplasmic fraction was more effectively separated from the whole organism than the membrane fraction was, most likely because the membrane fraction contained some whole cells or because cytoplasmic components adhered to membrane fragments. At least five to seven polypeptides could be specifically assigned to the cytoplasmic fraction and excluded from the membrane fraction.

Testing of the fractions by isoelectric focusing also permitted differentiation of cytoplasmic and membrane components (Fig. 7). Membrane fractions of type 1 showed two unique proteins fo- 


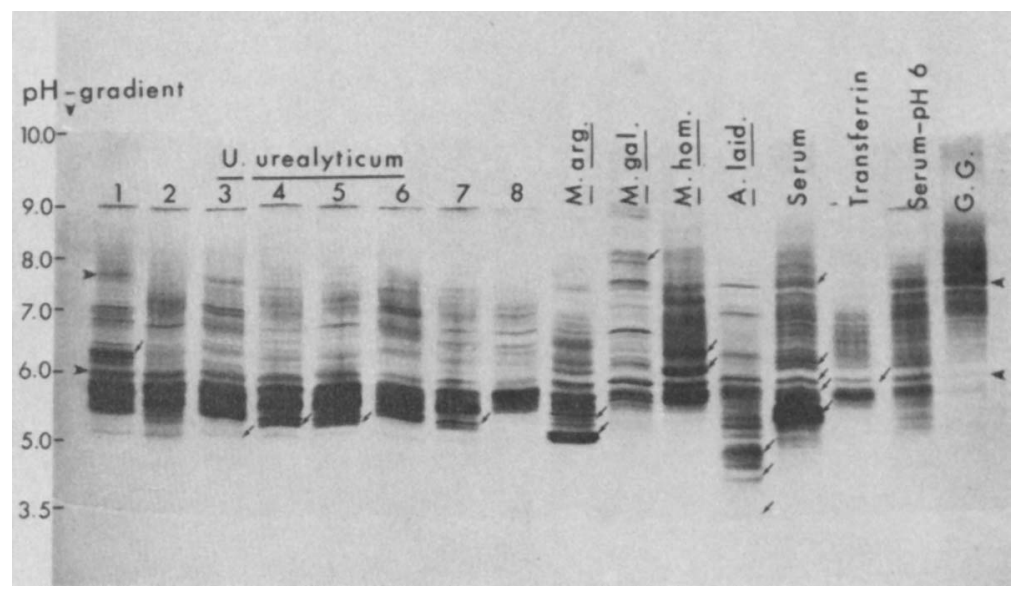

Fig. 3. Polyacrylamide gel isoelectric focusing of whole-cell lysates of strains of the eight serotypes of $U$. urealyticum, three species of Mycoplasma, and a representative of Acholeplasma; horse serum proteins were used as controls. From left to right the gels contained strains of $U$. urealyticum serotypes 1 through 8;M. arginini G-230, M. gallisepticum ATCC 15302, M. hominis ATCC 14027, A. laidlawii ATCC 14192, whole horse serum, horse transferrin, horse serum precipitate obtained at pH 6.0, and horse gamma globulins. Slanted arrows indicate major specific and common components.

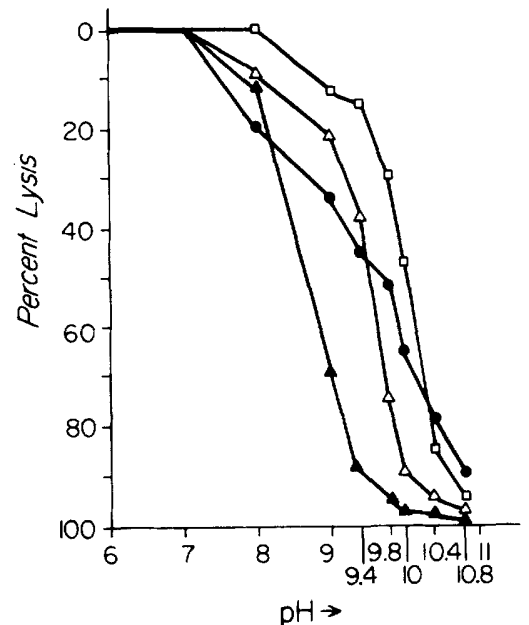

FiG. 4. Lysis of ureaplasmata, acholeplasmata, and mycoplasmata according to $\mathrm{pH}$. The lysis buffers used were $50 \mathrm{mM} \mathrm{MES}$ (pH 6.0), $50 \mathrm{mM}$ TES (pH 7.0 and 8.0), and carbonate-bicarbonate buffer ( $\mathrm{pH} 9.0$, $9.4,9.8,10.0,10.4$ and 10.8). Symbols: 1 strain of $U$. urealyticum serotype $8 ; \triangle, M$. gallisepticum $A T C C$ 15302; $\triangle$, M. hominis ATCC 14027; $\square$, A. laidlawii $A T C C$ 14192. Percent lysis $=(A-B) /(B-C) \times 100$, where $A$ is the optical density of a suspension in phosphate-buffered saline (no lysis), $B$ is the optical density of a suspension in the test system (variable degree of lysis), and $C$ is the optical density of a suspension in an aqueous solution of $75 \mu M S D S$ (complete lysis).

cusing at pK values of 6.5 (Fig. 7). These components were clearly absent in the cytoplasmic fraction and also in the fractions of the type 8 strain (Fig. 7). However, at pH 7, type 8 mem- branes were greatly enriched for a component (Fig. 7) which appeared to be an assembly of five proteins and which was specific to this type. Prominent cytoplasmic components focusing at pH 5.6 and 7.2 were found in both strains.

Contamination of $U$. urealyticum sediments with medium components. Washed cells of $U$. urealyticum and other members of the Mycoplasmatales are frequently, if not usually, contaminated with medium components, particularly insoluble peptone, yeast extract, and serum components, which cosediment with the

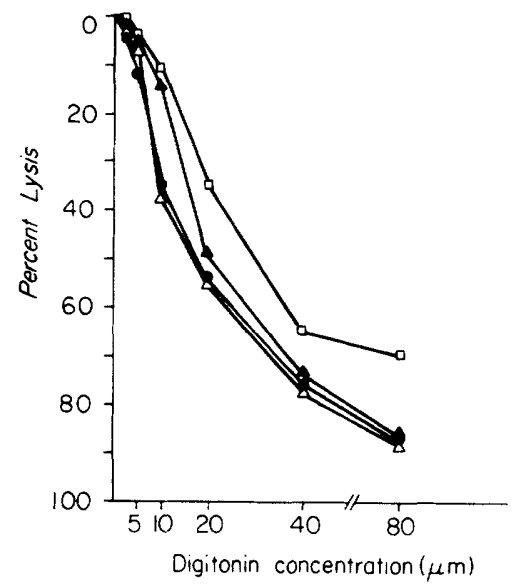

Fig. 5. Lysis at various concentrations of digitonin. Symbols: 0 , strain of $U$. urealyticum type $8 ; \boldsymbol{\Delta}$, M. gallisepticum ATCC 15302; $\triangle, M$. hominis ATCC 14027; $\square$ A. laidlawii ATCC 14192. Percent lysis was measured as described for carbonate lysis (see legend to Fig. 4). 


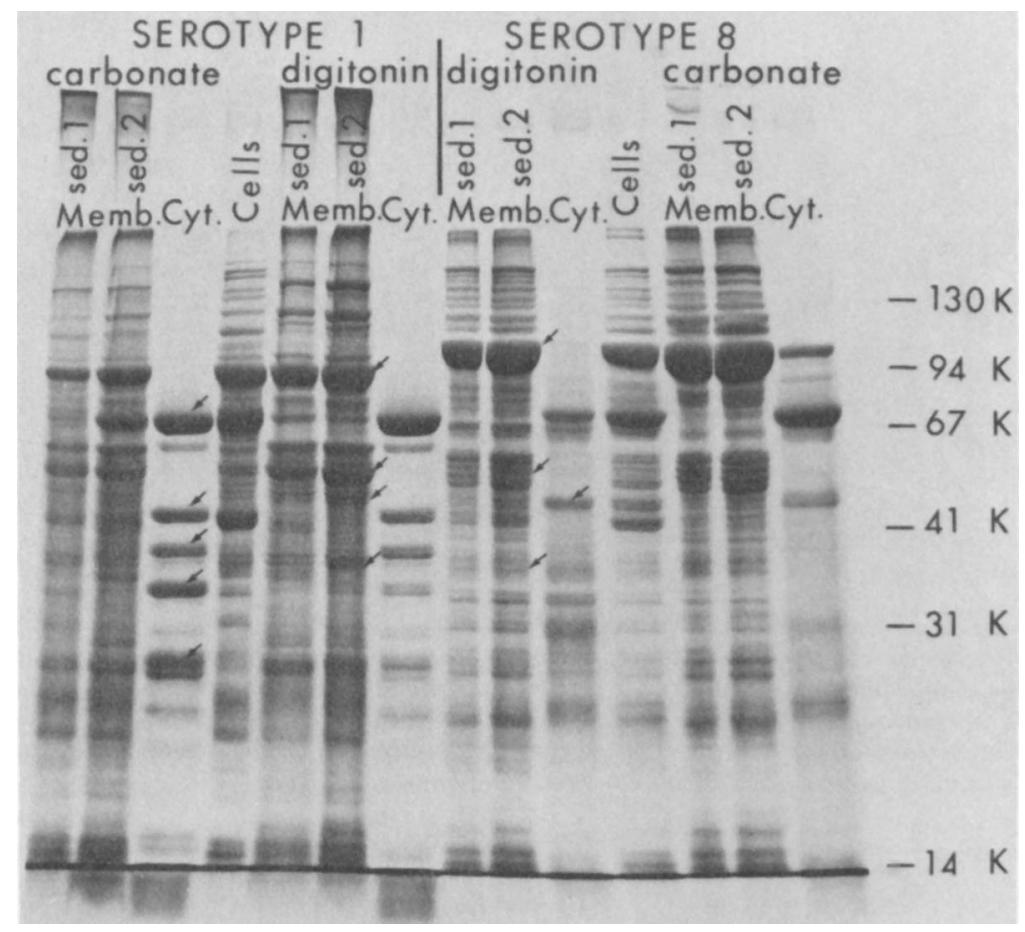

FIG. 6. SDS-polyacrylamide gel electrophoresis analysis of membrane and cytoplasmic fractions (prepared by carbonate-bicarbonate and digitonin methods) of strains of types 1 and 8 of U. urealyticum. The whole-cell lysate of each strain was used as a control for direct comparison to determine the specific polypeptides in the various fractions. Sediment 1 was obtained by centrifugation at 4,000 $\times \mathrm{g}$, and membrane sediment 2 was obtained by centrifugation at 40,000 $\times$ g. Assessment of molecular weights was made by using standard proteins, as described in the legend to Fig. 1. Slanted arrows indicate unique membrane and cytoplasmic components.

organisms and cannot be removed by washing of the organism pellet $(2,6,7,13,28)$. This problem has greatly frustrated attempts at analyzing cell fractions either biochemically (13) or immunologically (7). This problem can be evaded to an extent by the use of a dialysate broth base supplemented with agamma serum, which has been selected for its ability to remain clear during cultivation of the organism (5-8). In addition, in this study we filtered the dialysate broth base and used $1 \%$ serum (which we found to give cellular yields equivalent to the more usual higher serum concentrations) with a higher urea concentration in a strongly buffered medium to maximize yields for $U$. urealyticum (8). The degree of contamination with serum components was best shown by isoelectric focusing. We showed, for the first time, that a component migrating in the same location as a component of serum transferrin is found not only in ureaplasmata but also in mycoplasmata and acholeplasmata (Fig. 3, lower arrowhead). Other serum components are found in the acidic region of the gel (Fig. 3, upper arrowhead). Mycoplasmata are not known to possess cytochromes (12); however, a component common to all organisms was observed which comigrated with cytochrome $c$ in SDS-polyacrylamide gels in the 14,000-dalton region (Fig. 1 and 2, dense line which extends across bottom of all gels; another possible serum contaminant is indicated by the arrowheads in Fig. 2). Thus, contaminating components having molecular weights similar to those of transferrin, cytochrome $c$, and immunoglobulin fragments were identified in the organisms studied. The fact that ureaplasmata can be grown in dialysate broth with $1 \%$ serum, in contrast to the crude medium with 5 to $10 \%$ serum used in other studies $(11,15)$, probably accounts for the greatly reduced contamination observed in our study. An important ancillary control is the fact that the profiles of $U$. urealyticum strains are strikingly different from those of mycoplasmata grown in a similar medium, indicating that the major differences and similarities shown are specific to $U$. urealyticum. In fact, the failure in previous studies (19) to distinguish specific peptides in various $U$. urealyticum types must be 


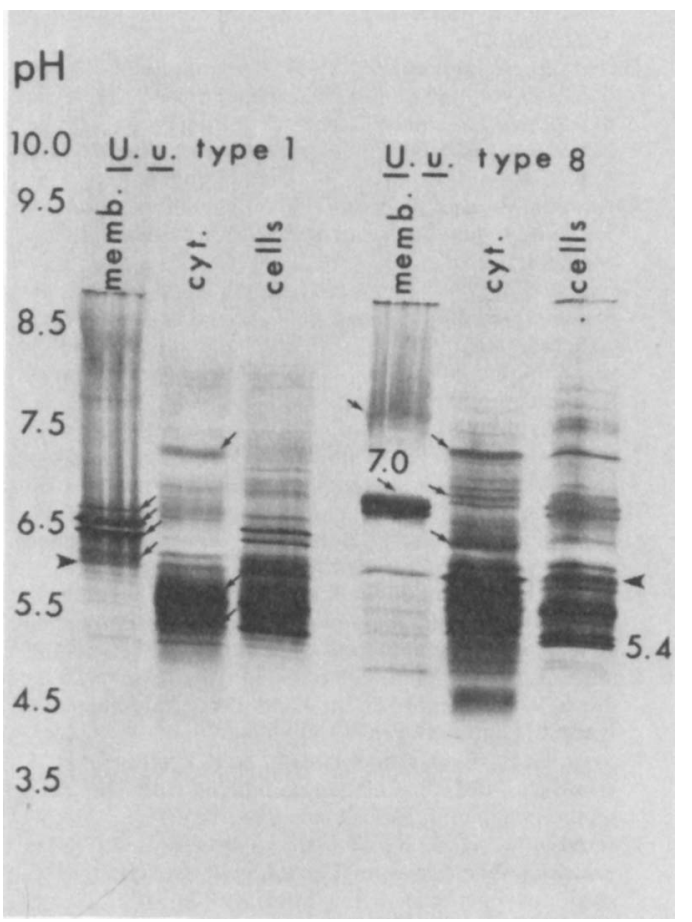

FIG. 7. Comparison of isoelectric focusing of mem. brane and cytoplasmic fractions with isoelectric focusing of the whole-cell lysates (prepared by the digitonin lysis procedure) of strains of $U$. urealyticum serotypes 1 and 8. Slanted arrows indicate specific components.

due in large part to contamination of the minute pellets with medium components.

\section{DISCUSSION}

The polypeptide patterns of the $U$. urealyticum strains were strongly similar when tested by SDS-polyacrylamide slab gel electrophoresis. However, most strains had at least one unique polypeptide present in a major amount. This association of specific polypeptides with given serotypes has not been demonstrated previously by polyacrylamide gel electrophoresis (15) using different techniques, namely, solubilization with phenol-acetic acid-urea (1) and employing tubegels $(15,17,29)$, in contrast to the SDS used for solubilization and estimation of molecular weights $(22,26)$ used in our study. The $U$. urealyticum patterns overall were sharply distinct from the patterns produced by three highly dissimilar organisms in the Mycoplasmatales: $A$. laidlawii, which does not require cholesterol (13) and whose genome is twice as large as that of $M$. gallisepticum, an organism which has a unique structure and utilizes glucose (13); and two serologically related arginine-utilizing orga- nisms, $M$. arginini and $M$. hominis $(7,25)$. How ever, no specific common polypeptide could be used to identify $U$. urealyticum because at least one of the heterologous organisms showed peptides of similar molecular weights in each case, an event which would occur by chance because of the large number of polypeptides present (Fig. 2). However, it may be possible to identify $U$. urealyticum by using a combination of peptides which are in common to all strains. For example, the pattern produced by peptides of 70,000 and 44,000 daltons (Fig. 1 and 2) appears to permit identification of the species $U$. urealyticum. The "gaps" between the polypeptide bands at 33,000 , 29,000 , and 25,000 daltons (Fig. 1, three lowest arrowheads) are particularly important markers since the organisms in the other genera had peptides observable in these areas, whereas the gaps were consistently present in all human ureaplasmic strains (Fig. 1 and 2). The close similarities shown among the strains of the $U$. urealyticum serotypes indicate strongly that these organisms are very closely related and that the original decision to divide these organisms into types rather than species (23) was probably correct. Although further comparative studies will be required to encompass the diversity observed in the Mycoplasmatales $(6,7,24)$, recognition of these specific markers or patterns or both may prove useful for identification of this species. Our study was focused at determining differences and similarities among the type strains of the eight serotypes of $U$. urealyticum. It remains to be determined whether the unique peptides demonstrated for the single representative strain of each serotype tested in our study will correlate with the antigenic determinant responsible for serotype differences or whether the unique peptides reflect biovar differences other than serotype among strains. Although few strains of a given serotype have been identified, considerable progress at identifying clinical isolates is now being made (23); this should permit comparisons of a number of strains of a given serotype.

The lytic methods used for ureaplasmata gave effective separation of cytoplasm from membranes, striking enrichment of the cytoplasmic fractions for specific components, and elimination of the major specific peptides of the types tested $(85,000$ daltons for type 1 and 95,000 daltons for type 8). However, the membrane fractions were not so clearly distinguishable from the whole lysed organisms by SDS-polyacrylamide gel electrophoresis; the major cytoplasmic peptides were greatly reduced in quantity, but a number of the peptides in the lowermolecular-weight region were found in both the membrane fractions and lysed whole organisms. 
Nonetheless, the present data suggest strongly that the major specific peptides are membrane components. The fact that ureaplasmata are susceptible to digitonin (11) is not surprising in view of their requirement for cholesterol, nor is the lysis of $A$. laidlawii by digitonin remarkable since Razin and Argaman (14) have shown that acholeplasmata only resist digitonin lysis when the organisms are grown in cholesterol-free medium (which was not done in the present experiments). In a recent study, Romano and LaLicata (16), using the procedure of Masover et al. (11) and ultrasonic disruption, claimed that ultrasonic treatment provided membranes of superior quality compared with those obtained by digitonin lysis. However, it is now evident from our studies that effective lysis of ureaplasmic cells requires both a higher concentration of digitonin and a lower amount of protein $(150 \mu \mathrm{g}$ of protein per $\mathrm{ml}$ of $40 \mu \mathrm{M}$ digitonin) than used in those studies $(11,16)$.

The degree of separation of the fractions separated much greater when they were tested by isoelectric focusing (Fig. 7). The cytoplasmic fractions were clearly greatly enriched for the more acidic components, whereas the membrane fractions had little of these components. Two major specific membrane proteins could be resolved for type 1 at $\mathrm{pH} \mathrm{6.5,} \mathrm{and} \mathrm{another} \mathrm{major}$ specific peptide was observed at $\mathrm{pH} 7.0$ for type 8. Interestingly, the number of Tween-soluble proteins on isoelectric focusing was considerably less than the number seen with SDS-polyacrylamide gel electrophoresis (Fig. 6 and 7), whereas the reverse was true for cytoplasmic proteins. The differences between SDS-polyacrylamide gel electrophoresis and isoelectric focusing derive from the fact that a strong ionic detergent was used for the former and a nonionic detergent was used for the latter, as well as from the fact that isoelectric focusing is sensitive to the substitution of a single or few amino acids of a different charge, whereas SDS-polyacrylamide gel electrophoresis is sensitive only to significant changes in molecular weight.

\section{ACKNOWLEDGMENTS}

This study was supported in part by Public Health Service research grant AI-06720 from the National Institute of Allergy and Infectious Diseases and by Public Health Service training grant GM-07187 from the National Institute of General Medical Sciences.

\section{REPRINT REQUESTS}

Address reprint requests to: Dr. George E. Kenny, Department of Pathobiology, SC-38, School of Public Health and Community Medicine, University of Washington, Seattle, WA 98195 .

\section{LITERATURE CITED}

1. Bagdasasian, M., N. A. Matheson, R. L. M. Synge, and M. A. Youngson. 1964. New procedures for iso- lating polypeptides and proteins from tissues. Biochem. J. 91:91-105.

2. Bradbury, J. M., and F. T. W. Jordan. 1972. Studies on the adsorption of certain medium proteins to $\mathrm{Myco}$ plasma gallisepticum and their influence on agglutination and haemagglutination reaction. J. Hyg. 70:267278

3. Dulbecco, R., and M. Vogt. 1954. Plaque formation and isolation of pure lines with poliomyelitis viruses. J. Exp. Med. 99:167-182.

4. Goel, M. C. 1973. New method for the isolation of membranes from Mycoplasma gallisepticum. J. Bacteriol. 116:994-1000.

5. Kenny, G. E. 1967. Heat-lability and organic solventsolubility of Mycoplasma antigens. Ann. N.Y. Acad. Sci. 143:676-681.

6. Kenny, G. E. 1969. Serological comparison of ten glycolytic Mycoplasma species. J. Bacteriol. 98:1044-1055.

7. Kenny, G. E. 1979. Antigenic determinants, p. 351-384. In M. F. Barile and S. Razin (ed.), The mycoplasmas, vol. 1. Academic Press Inc., New York.

8. Kenny, G. E., and F. D. Cartwright. 1977. Effect of urea concentration on growth of Ureaplasma urealyti. cum (T-strain mycoplasma). J. Bacteriol. 132:144-150.

9. Laemmli, U. K. 1970. Cleavage of structural proteins during the assembly of the head of bacteriophage T4. Nature (London) 227:680-685.

10. Lowry, 0. H., N. J. Rosebrough, A. L. Farr, and R. J. Randall. 1951. Protein measurement with the Folin phenol reagent. J. Biol. Chem. 193:265-275.

11. Masover, G. K., S. Razin, and L. Hayflick. 1977. Localization of enzymes in Ureaplasma urealyticum (Tstrain mycoplasma). J. Bacteriol. 130:297-302.

12. Pollack, J. D. 1979. Respiratory pathways and energyyielding mechanisms, p. 187-211, In M. F. Barile and S. Razin (ed.), The mycoplasmas, vol. 1. Academic Press Inc., New York.

13. Razin, S. 1978. The mycoplasmas. Microbiol. Rev. 42: 414-470.

14. Razin, S., and M. Argaman. 1963. Lysis of mycoplasma, bacterial protoplasts, spheroplasts and L-forms by various agents. J. Gen. Microbiol. 30:155-172.

15. Raxin, S., J. Valdesuso, R. H. Purcell, and R. M. Chanock. 1970. Electrophoretic analysis of cell proteins of T-strain mycoplasmas isolated from man. $J$. Bacteriol. 103:702-706.

16. Romano, N., and R. LaLicata. 1978. Cell fractionation and enzymatic activities of Ureaplasma urealyticum. J. Bacteriol. 136:833-838.

17. Rottem, S., and S. Raxin. 1967. Electrophoretic patterns of membrane proteins of Mycoplasma. J. Bacteriol. 94: 359-364.

18. Rottem, S., and S. Raxin. 1972. Isolation of mycoplasma membranes by digitonin. J. Bacteriol. 110:699-705.

19. Sayed, I. A., and B. A. Hatten. 1976. Isoelectric focusing of mycoplasma proteins. Appl. Environ. Microbiol. 32: 603-609.

20. Sayed, I. A., and G. E. Kenny. 1978. Effect of ammonium ion concentration and osmotic pressure on growth of Ureaplasma urealyticum (T-strain mycoplasma). J. Bacteriol. 134:962-967.

21. Sayed, I. A., and G. E. Kenny. 1979. Effects of reducing agents, catalase, and medium reuse on toxicity of media for growth of Ureaplasma urealyticum. J. Infect. Dis. 139:720-724.

22. Shapiro, A. L., E. Vinuela, and J. V. Maizel. 1967. Molecular weight estimation of polypeptide chains by electrophoresis in SDS-polyacrylamide gels. Biochem. Biophys. Res. Commun. 28:815-820.

23. Shepard, M. C., and C. D. Lunceford. 1978. Serological typing of Ureaplasma urealyticum isolates from urethritis patients by an agar growth inhibition method. $J$. Clin. Microbiol. 8:566-574. 
24. Shepard, M. C., C. D. Lunceford, D. K. Ford, R. H. Purcell, D. Taylor-Robinson, S. Razin, and F. T. Black. 1974. Ureaplasma urealyticum gen. nov., sp. nov.: proposed nomenclature for the human $T(T$. strain) mycoplasmas. Int. J. Syst. Bacteriol. 24:160-171.

25. Thirkill, C. E., and G. E. Kenny. 1974. Serological comparison of five arginine-utilizing Mycoplasma species by two-dimensional immunoelectrophoresis. Infect. Immun. 10:624-632.

26. Vesterberg, 0.1973 . Isoelectric focusing of proteins in thin layers of polyacrylamide gel. Sci. Tools 20:22-29.
27. Weber, K., and M. Osborn. 1969. The reliability of molecular weight determinatiions by dodecyl sulfatepolyacrylamide gel electrophoresis. J. Biol. Chem. 244: 4406-4412.

28. Yaguzhinskaya, O. E. 1976. Detection of serum proteins in the electrophoretic patterns of total proteins of mycoplasma cells. J. Hyg. 77:189-198.

29. Zola, H., W. Baxendale, and L. J. Sayer. 1970. Polyacrylamide gel electrophoresis of lysates of mycoplasmas. Res. Vet. Sci. 11:397-399. 